Revista PSICOLOGIA, 2016, Vol. 30 (2), 47-60. doi: 10.17575/rpsicol.v30i2.1111

\title{
"The place I long to be": Resilience processes in migrants
}

\author{
Sandra Roberto ${ }^{1}$, Carla Moleiro ${ }^{1}$, Nuno Ramos ${ }^{1}$ e Jaclin Freire ${ }^{1}$ \\ ${ }^{1}$ Instituto Universitário de Lisboa ISCTE-IUL, Cis-IUL, Lisboa, Portugal
}

\begin{abstract}
Migration has been addressed in studies with a marked focus on its obstacles and difficulties, particularly in the contact with the host country. Recognizing that migrating is a complex process that involves several hardships, it is imperative to understand how migrants overcome adversity and to become aware of the resources mobilised to be cultural adjusted. Based on the theoretical perspective of resilience, this study aims to understand the contexts of adversity, resources and adjustment of Cape Verde migrants in Portugal, who have migrated to continue their studies in higher education. The collected 10 biographical narratives revealed the meanings of their life journeys, both in their country of origin and in the host country. The analysis of the narratives allowed the understanding of the diversity of resilience processes among the participants. The adversities were related to two main dimensions: cultural differences and interpersonal relationships with the Portuguese. In terms of resources, participants stressed the importance of the Cape Verdean diaspora upon arrival to the new country. Along the length of stay for some migrants, this remained the main resource; however, others were developing belongings and significant attachments in a broader context. In terms of cultural adjustment, many configurations have emerged, standing for the fluid nature of the resilience process, which can occur in different ways.
\end{abstract}

\section{Keywords: Resilience; Migration; Transnationalism; Autobiographical narratives.}

“The place I long to be": Processos de resiliência em migrantes: As migrações têm sido abordadas através de estudos com um enfoque particular nos obstáculos e dificuldades, nomeadamente no contacto com o país de acolhimento. Reconhecendo que migrar é um processo complexo que envolve várias dificuldades importa compreender o modo como os migrantes superam a adversidade, bem como se torna importante conhecer os recursos mobilizados para serem culturalmente ajustados. Partindo da perspectiva teórica da resiliência, este estudo procurou compreender os contextos de adversidade, recursos e ajustamento dos migrantes cabo-verdianos em Portugal, que migraram para continuar os estudos no ensino superior. As 10 narrativas biográficas recolhidas revelaram significados das suas trajetórias de vida, tanto no país de origem como no país de acolhimento. A análise das narrativas permitiu compreender a diversidade dos processos de resiliência entre os participantes. As adversidades relacionaram-se com duas principais dimensões; as diferenças culturais e as relações interpessoais com os portugueses. Ao nível dos recursos, foi salientada a importância da diáspora cabo-verdiana na chegada ao novo país. Ao longo do tempo de permanência, para alguns migrantes, este permaneceu como o principal recurso, no entanto, outros foram desenvolvendo pertenças e vinculações significativas num contexto mais alargado. Em termos de ajustamento cultural, surgiram diversas configurações, sugerindo a natureza fluida do processo de resiliência, que pode ocorrer numa multiplicidade de formas.

Palavras-chave: Resiliência; Migração; Transnacionalismo; Diáspora; Narrativas.

Studies on migrants have addressed the adversities and negative consequences on migrants' arrival and permanence over time in a new country. In general, a range of assumed issues are related to the barriers and obstacles regarding contact with host societies as well as a list of the various migrants' losses (e.g. family ties, language, cultural frame of reference) after leaving their country of origin (e.g. Berry, 1997; Boss, 2006; Utsey, Giesbrecht, Hook, \& Stanard, 2008).

Although these processes are present and possibly simultaneous, few studies have devoted attention to the dynamic processes involved in the interaction between adversities and resources (which is the basic assumption of resilience for some authors, e.g. Davydov, Stewart, Ritchie, \& Chaudieu, 2010; Luthar, Cicchetti, \& Becker, 2000; Luthar, Sawyer, \& Brown, 2006; Ungar, 2008) when in the host country. The theoretical perspective of resilience has a proposal complementary to the perspective rooted in adversity. The concept's basic notion recognises the existence of adverse contexts but focuses on

\footnotetext{
1 Address for correspondence: Sandra Roberto, Avenida das Forças Armadas, Edificio II, $1649-026$ Lisboa, Portugal E-mail: sandragasroberto@gmail.com
} 
mobilised resources to overcome adversity in positive adjustment processes (Luthar, Cicchetti, \& Becker, 2000).

In migration literature, a lot of studies focus on the period between arrival and permanence over time in the host country from the perspective of social and cultural differences and contrasts (e.g. Noh \& Kaspar, 2003; Padilla, Cervantes, Maldonado, \& Garcia, 1998; Yakushko, 2010), excluding part of the journey made in the country of origin (Yijälä \& Jasinskaja-Lahti, 2010). In this sense, the concept of transnationalism goes beyond the division between countries and proposes an understanding through an approach that goes beyond national borders, "Transmigrants take actions, make decisions, and develop subjectivities and identities embedded in networks of relationships that connect them simultaneously to two or more nation states" (Basch, Schiller, \& Szanton-Blanc, 1994, p.7).

Seeking to know more about resilience and migration from the transnationalism perspective, this study was conducted to understand the migration process, observed through the continuity between country of origin and host country. Based on this, an understanding of the adversity, resources and adjustment in life paths was sought. Therefore, we hoped to study the meanings attributed by Cape Verdean migrants to their life in the country of origin, including the decision to migrate. Cape Verde is a country profoundly marked by migration since its independence from Portugal, and its diaspora had a tremendous importance in consolidating its transition to an autonomous state. Barata and Carling (2008) state that few countries in the world have been as marked by migration as Cape Verde. Simultaneously, Cape Verdean communities around the world are consolidated or 'mature'-in the words of Carling (2003) - and they are typically engaged in transnational practices in host countries. In Portugal, Cape Verdeans are the oldest consolidated migrant community with an enormous diversity of transnational practices.

In this study, we also wanted to understand the meanings attributed by migrants to their migratory transition and the changes that occurred in the length of stay in Portugal. Through this approach, we tried to understand the resources that enable the migrants to overcome the difficulties faced in the host society. With this goal in mind we use the concept of resilience as a process that may take multiple configurations. As such, this study focuses on the individual in the social and cultural context and as an agent and product of the interaction with contexts.

\section{Resilience and Migration}

The conceptual proposal of this study was built on fundamental concepts that have interdisciplinary and distinct epistemological foundations. Thus it is necessary to clarify these concepts and address the ways that they are connected.

The concept of resilience emerged from knowledge gathered in positive psychology, epistemologically based on a positivist perspective. The study of positive psychology encourages a shift from the focus on deficit or disease to the strength in human condition and development (Seligman, 2002). Studies in this field have sought to assess how individuals use certain resources when faced with adverse contextual determinants. Therefore, one possibility of the concept's definition used in empirical research (though there are other points of view, such as an understanding as trait or result of a process; Richardson, 2002) refers to resilience as a dynamic and circumstantial process. It consists of a positive adjustment or adaptation due to the action of protective factors in adverse circumstances or conditions (Luthar et al., 2000).

Many studies have operationalized the concept through a predictive approach, searching for the influence of protective factors in order to predict resilience even in the presence of risk factors. In this study, however, we complied with Yunes' (2003) proposal instead, highlighting the need for studies with an approach based on the subjective dimension of resilience that capture the meanings assigned by people to their individual experience. This idea opens the door to communication with other epistemological foundations. We aimed to understand resilience as a dynamic and circumstantial process based on the building and sharing of socially constructed meanings. Ungar (2008) has highlighted concern regarding a certain hegemony in studies about resilience and, as such, seeks to include the cultural dimension in the definition. In this article we adopted the concept of resilience defined as follows: 'In the context of exposure to significant adversity, resilience is both the capacity of individuals to navigate their way to the psychological, social, cultural, and physical resources that sustain their well-being, and their capacity individually and collectively to negotiate for these resources to be provided and experienced in culturally meaningful ways' (Ungar, 2008, pp. 225. According to this definition, emphasis is given to the importance of the cultural foundations (that form each person individually) involved in the ability of individuals to navigate and negotiate for the resources they need.

The characteristics and idiosyncrasies of the Cape Verdean community were specifically analysed through the lenses of the transnationalism concept for the general purpose of understanding migration 
processes. Transnationalism is defined as 'the process in which immigrants create social fields linking their country of origin with the country where they have settled' (Schiller, Basch, \& Blanc-Szanton, 1992, pp. 81). This reinforces the need to recognise the link between the point of departure and arrival without losing sight of the real, continuous and uninterrupted process that characterises this movement (Gois, 2008; Gois \& Marques, 2008). In other words, a look at Cape Verde transnationalism can be a valuable tool for understanding various areas of interest, such as the management of cultural heritage between the community of origin and the host country, the physical and emotional connection that is maintained, strengthened and transformed within the country of origin, or the new established attachments, as reported by other authors who studied transnationalism (e.g. Portes, Guarnizo, \& Landholt, 1999). In the case of Cape Verdeans, the country of origin will always be a strong reference point (Évora, 2006), shaped by colonial and post-colonial history as well as the relations of independence and dependence with Portugal.

Numerous perspectives can be adopted when the studies of resilience and migration are considered together. One of the most significant aspect is to focus on the relation of adversity, resources and positive adjustment to cultural specificities. Among studies about acculturation, Berry (2001) suggested that the best form of adjustment for migrants is the reciprocal integration and interaction of cultures (from origin and host countries). However, other authors (e.g. Babha, 1994; Vertovec, 2001) brought other proposals beyond bi-culturalism, demonstrating that migrants are not necessarily oriented towards the origin or destination country, being capable of orientation to various places, communities and societies at the same time (Vertovec, 2001). Thus, the positive adjustment proposed by the concept of resilience, in this study it will be understood as cultural adjustment. If the concept of transnationalism proposes a variety of views on how migrants achieve a positive adjustment in relation to cultures, so the resilience processes can occur in different ways-as many as the existing possibilities in the individual relationships of migrants with cultures.

Using the concept of transnationalism, this study aimed to understand the resilience processes of Cape Verdean migrants through the meanings attributed to their life paths. We explore the dynamics between adversity and resources that lead to cultural adjustment in the continuity between the country of origin and the host country. The proposal of abductive logic, designed to meet the goal of the research, assumes (as stated by Reichertz [2009]) an open attitude towards the discovery of new meanings and significances. The biographical narratives were chosen as the vehicle that enables the understanding of the migration processes from a qualitative perspective.

\section{Cape Verde migration in Portugal}

The migratory movement from Cape Verde to Portugal consists of different phases, having started with a long tradition of migration reported since the eighteenth century (Carita \& Rosendo, 1993). Always against the backdrop of "abandonment, repopulation and recurrent droughts" (Grassi, 2006, p. 2) and justified as being necessary and inevitable, the history of Cape Verdean migration can be explained through different flows, destinations, causes and people.

The latest and steady migration wave to Portugal occurred from the 1960s onwards, with its greatest intensity in 1974-1975 (Carita \& Rosendo, 1993). If the movement was initially mainly associated to the entry of technical staff, higher education individuals or employees of public and colonial administration (Carita \& Rosendo, 1993), it quickly changed. It was the beginning of the arrival of a great number of men who travelled with the main goal of covering manpower shortages in the construction and public work industries that were in expansion back then (Grassi, 2006). In addition to this migrant population, with at least a decade of residence in Portugal, many Cape Verdean family members entered the host country through family reunion, including siblings, wives and children (Carita \& Rosendo, 1993). However, due to bureaucratic and administrative barriers, the legal migration flow decreased, giving way to the entry of undocumented Cape Verdean migrants, which represented up to $50 \%$ of the Cape Verdean population in Portugal, at that time (Grassi, 2006). Along these different phases in migratory movement, it is important to highlight the movement of many young Cape Verdean people arriving to attend institutions of technical and higher education, which also represent a key component in the migratory dynamics of this population.

The presence of Cape Verdean migrants in Portugal becomes an issue of great relevance, not only because it is the second largest migrant community but more so owing to the fact that it is the oldest one. That is to say, this community has remained relatively constant in size and has had a number of "migration cycles" already in Portugal (Machado, 2005). However, statistical data are discordant between Cape Verdean and Portuguese authorities (Batalha, 2008). In 2003, the Institute of Cape Verde Communities (IC-CV) reported that the number of citizens from this archipelago living in Portugal exceeded 100,000 individuals, while in the same year, the Immigration Report Frontiers and Asylum 
(RIFA) of Foreigners and Borders Service (SEF) indicated that this number did not exceed 54,000. The last RIFA (2013) accounts for the presence of 42,401 legal Cape Verdean residents, representing 11\% of the foreign population in Portugal.

Studies on the Cape Verdean migrants in Portugal have been less abundant (Machado, 2005), and those that exist are typically produced by social science subjects, such as sociology or anthropology (e.g. Carita \& Rosendo, 1993; Évora, 2006; Grassi, 2006).

This study was conducted with Cape Verdean migrants who arrived to pursue their studies in Portuguese universities. We selected this specific migrant population because studies about Cape Verdeans in Portugal tend to focus on the ones that leave Cape Verde in disadvantaged socio-economic and professional conditions (who remain in the same conditions in Portugal as well). Nevertheless, a significant number of Cape Verdeans arrive in Portugal to receive higher education, and a part of them remains in the country (Carita \& Rosendo, 1993), Therefore, this type of migration brings some specificity, since the starting conditions of the migrants may be different when compared with migrations due to other reasons and motivations (political and economic ones, amongst others). Through the complexity of their life paths, we wanted to understand more about the challenges these migrants face and the resources they mobilise.

\section{METHOD}

In studies on migration, various methods of conducting and analysing biographical narratives have been used mostly in the tradition of phenomenological narration analysis and objective hermeneutics (Apitzsch \& Siouti, 2007). In this study, we used the case reconstruction method (Fischer-Rosenthal \& Rosenthal, 1997), because it seems very well adjusted to the studies on transnationalism in migrants. The basic idea is that through the reconstruction process of each case, it is possible to gain access to the interaction between the individual and institutional aspects of social reality. "Our aim is rather to reconstruct the interactional significance of the subject's actions, the underlying structure of the biographers' interpretations of her or his life, which may go beyond the subject's own intentions" (Rosenthal, 1993, pp.60). For this purpose, as mentioned by the authors, it uses the principles of abduction and sequentially, without losing sight of the narrative perspective as a whole (Gestalt). The principle of abduction is applied because it does not have any particular theory in view and expects that surprising facts will be discovered. The principle of sequentially highlight that social activity is a sequence of actions that involves choices in every situation, independently of the narrator's perspective. Applying this principle in the analysis means looking at the range of possibilities open to the subject in a certain situation, the selection that is made, the possibilities ignored and the consequences of the decisions. So, the sequential analysis involves interpretation through the reconstruction of the meaning of the text following the sequence of events (Rosenthal, 1993).

\section{Procedures}

We adopted the theoretical considerations on how to conduct the interview in the traditional formulation adopted by Schutze (1983, cited by Apitzsch \& Siouti, 2007) and Rosenthal (1993). These authors suggest an open introductory question to start the autobiographical narration and allowing the narrator to spontaneously tell his/her life story until he/she indicates that the narrative is concluded. It is distinguished from other methods because of the assumption that there are two levels of analysis in each narrative; the life story as it was lived and the narrated story. By distinguishing between these two levels, as well as analysing the relation between them, it is possible to carry out the reconstruction process in each case in a process-oriented manner.

The interview was conducted in order to integrate the abovementioned theoretical considerations. Thus, the opening question for this study was formulated as follows: "I would like to ask you to tell me your life story, all experiences and events that you remember. You can take the time you want. I will not interrupt you. Only at the end I will make some questions." After the conclusion of the narrative, as the narrator indicates, some questions were presented as to the need for the clarification of the reported content, particularly ambiguities, gaps, hesitations or contradictory information (Schutze, 1983, cited by Apitzsch \& Siouti, 2007).

The participants of this study were initially contacted through the participants of a previous study, using the snowball technique. These people were asked to appoint somebody from the Cape Verdean community that had been in Portugal for more than 2 years. The meeting and the development of the narratives occurred in places chosen and suggested by each participant. Thus, some narratives took place in the houses of the participants, others in cafés they used to go to, or intended to this end. At each meeting the objective of the study was explained, as well as the dimensions of voluntary participation and the guarantee of the protection of their confidentiality and anonymity in information treatment, and each 
participant signed an informed consent form. This study complied with the principles of the code of ethics of psychologists in Portugal (Ordem dos Psicólogos Portugueses [Order of Portuguese Psychologists], 2010).

The narratives were conducted by the first author of this study and voice recorded. Subsequently, this information was transcribed by an investigation assistant, and the voice-recorded information was used again in the process of analysis of the narratives, simultaneously to the text of the transcriptions. The narratives had durations varying between 45 minutes and $2 \mathrm{~h} 10 \mathrm{~m}$; the full transcription of each interview and the respective notes were followed by the method of analysis.

The analysis of the case reconstruction narrative in this study followed the aforementioned authors' proposal, systemised in five sequential stages (these stages are explained in detail in the method section of the article; Fischer-Rosenthal \& Rosenthal, 2004): (1) analysis of biographical data; (2) Text analysis and thematic areas; (3) Reconstruction of life story; (4) Detailed analysis of individual text segments; (5) Contrasting life story as narrated with life as it was lived.

The stages of the presented reconstruction method aim to find the process of the narrative creation in the present life, without losing sight of the reciprocal relationship between both of them and the unity of the case. Due to space limitations and meeting the objective of this study, this article will not present the analysis in each of these steps, choosing to present the final results of the reconstruction cases.

The analysis of the narratives was elaborated and reformulated systematically by the authors of this article, implementing the stages of the method and following the meanings attributed by participants to their migratory experiences. The analysis was performed first by one of the authors, and then made by two other researchers. In the end, the analysis of each of the researchers was discussed by all in order to reach a consensus. The case reconstruction method has a subjective nature that is inherently related to the subjectivity of researchers who use it as a way to know the life experience of the participants. In this study, all authors work in research projects on cultural diversity and three of them are migrants or direct descendants of migrants. Their migratory experiences are also present in the way migration processes are understood, in general and particularly in this study. The personal experience of researchers can help to empathize with the narratives of migrants, for recognizing this experience in their own lives.

\section{Participants}

We collected 10 narratives of six men and four women, between 22 and 36 years old, living in the urban area or in the outskirts of Lisbon. Among these migrants, three were still studying and six had already completed their studies in higher education, thus already integrated in the labour market (two in Computer Science and one each in Law, Civil Engineering, Social work and Sociology). One had abandoned studies and was working as hairdresser. All participants' names were kept anonymous, and pseudonyms were given to them.

\section{RESULTS}

The biographical narratives were grouped by common and salient features in the form of contact with the host country while simultaneously bringing other common aspects of the country of origin. Following the proposal of Hollway and Jefferson (2000, chapter 6), we decided to group narratives to gather common characteristics in a larger and heterogeneous group of participants in an attempt to retain also the individual expression of the meanings assigned by migrants. The common aspect that characterised each group is the similar configuration in the cultural adjustment and the use of the resources (mainly attachments and belongings) developed over time in Portugal. In each group, we intended to highlight the relationship with the diaspora, feeling of belonging, direction of the attachments, recreation of cultural practices and the shape of the cultural adjustment. Following this purpose, four groups were created: (1) Death of motherland? Tensions in perspective; (2) Here as there-Cape Verde's heat; (3) The world is overseas; (4) To stay or to go back? Missing morabezza.

\section{Death of motherland? Tensions in perspective}

Adriano, 34, from the Island of Fogo (15 years of residency in Portugal), talks about a past marked by the separation of his parents at the age of eight, the father's absence and long hours without his mother, who had two jobs to support him and his brother. Soraya, 36, native of São Vicente (17 years in Portugal), shares very little about her childhood and gives away nothing about her life in Cape Verde, referring vaguely to the way it was as "a good time, as per normal standards".

Both experienced financial struggles in Portugal due to the loss of the scholarship provided by the Government of Cape Verde. As a result of a lack of academic success, they were forced to manage school with precarious jobs. Adriano admits to having had a hard time juggling work and studying, all the while 
finding it difficult to follow school standards with insufficient study methods in Computer Engineering. Soraya, on the other hand, studied law. She highlights other initial difficulties, such as weather shock, referring to a particular chill she used to feel-coldness in the soul. This made it difficult to go to classes, which took place in the morning: "It was very hard for me in first year, I'd sleep a lot, I'd sleep until noon". The contrast of rhythms in the new country and other differences such as the existence of an elderly Portuguese population, poor responsiveness from Portuguese people regarding interpersonal relationships and a cold and unwelcoming population were additional difficulties. During this period, the most significant relationships were established with Cape Verdean colleagues who also studied in Lisbon, with whom she rented a house and whom Soraya considers as sisters.

On the relations with the Portuguese and the differences between countries, Adriano and Soraya experienced different tensions. However, they both felt a certain pressure related to loyalties and affiliations, between preserving the past, the origins and the links in the present. For Adriano, entering the labour market brought the possibility of feeling welcomed by Portuguese people, "I joined the company in which I work today, which is a small but very consistent company that always has good customers and I am very cherished by my bosses, who are very fair and very honest. I really enjoy working there".

At the same time, when entering the Portuguese job market, Adriano rediscovered Cape Verde culture: "Since I have been here, I learned to appreciate the music when I first started playing the guitar, but after living here I actually really enjoyed it. Before that, I didn't like "morna". And I also didn't like "cachupa". "Cachupa' made on Saturday containing broth and meat ..." This proximity to the traditional culture of Cape Verde accompanies the desire to not go back. However, Adriano's wife would like to return to Cape Verde, generating other tensions related to this division between places and cultures: "I'm not ready to go back, if I have to I will. I think that it's really a matter of loyalty to the company, too. I'd like my daughter to be Cape Verdean just like me that she could be born with the culture. But I also don't mind at all that she's Portuguese and I made sure to teach her the language, I'm afraid of the bilingual issue, that it might confuse her".

The tensions felt by Soraya materialised in a different way but with the same result as Adriano's in terms of choices and possibilities in the new country that run counter to the country of origin. Soraya married a Cape Verdean who intends to live in Lisbon and is averse to the idea of returning to Cape Verde. Apparently, she ended up remaining in Portugal for him, despite the tension experienced with the Portuguese way of life. "It was supposed to be only five years and then leaving, I was only going to complete my studies and not live here ... There are seats here in which I'm faced directly opposite the other passenger and sometimes I sat there and people won't even greet me. That kind of thing is normal here, but not in Cape Verde! Nowadays, I act that way too; I don't even remember ever being "different" any more".

\section{Here as there-Cape Verde's heat}

Ângela, 29, born in Santiago, grew up in limited financial resources. The beginning of her adolescent life in Cape Verde was the basis for later choices in her life. Regarding this period, Ângela says, "I was about to turn 18, and I wanted to go out with my friends more, but my father wouldn't let me and I was beginning to turn against him. I thought he wasn't being fair with me. And my mother also wouldn't let me because she was afraid of him ... I started to rebel ..." In this context, Ângela felt that the male-dominated society of Cape Verde was too oppressive for women-promoting their dependency and preventing the freedom of choice.

Deise, 32, was born and raised on the island of São Vicente in a large family with many financial difficulties and dealt with the tragic event of the death of both parents when she was six years old. Deise started working at the very young age of 13, without dropping out of school. At the time, she discovered the Seventh-Day Evangelical Church of the 7th day, where she found encouragement from other believers to not give up, "Thank God I always had the privilege of finding people who helped me, who were always by my side ... I owe that to God, because He always provided people to help me". When she completed the 12th grade, she applied for a scholarship to study in Portugal with the support of the church.

Adilson, 22, was born on the island of Boavista, a deeply rural environment isolated from larger villages, where his family was dedicated to agriculture and livestock. "My routine always consisted of going to school early and, later in the day, I looked after the animals and I hardly had any time to study. But I always got good marks ... There were no roads, only rocks ..."

Ângela, Deise and Adilson left Cape Verde in different socio-economic conditions although they had few financial resources and different motivations to study abroad. For Ângela, the decision to study in Portugal was related to her father, attending a study course that he considered important for the future (marketing and advertising), which she later abandoned due to not being able to pay rent. "I've been 
saying since I was a child, "I want to be a hairdresser!" and that dream slowly died. After that, when I came here to study, I was here mainly for my dad. (...) but things didn't end up that way, when I first started working at the hair salon I loved it, and I still do. I do it of my own volition, not because I was pushed to it". This opportunity for Ângela came through her aunt who lives in Lisbon and knew the hair salon owner.

Their life paths grow closer in the difficulties they faced in Portugal due to periods of instability and insecurity (namely, demanding financial needs, illegal stays in the country or psychological distress) that threatened their stay in Portugal despite the desire for permanence. Deise went to Portugal to study social work with the support of a scholarship, faithful contacts at the Church and acquaintances of Cape Verdean friends also studying in the country. These people were crucial in helping her with the difficulties faced during this period. On the one hand, the scholarship amount was low compared to monthly expenses, sometimes cutting short basic needs such as food. On the other hand, Deise felt attacked with disrespectful and derogatory comments about her origins: "People in the street make fun of me, saying 'black girl' and stuff like that (...) They regard Cape Verde as an underdeveloped country, a country of dumb people". Ângela faced marked difficulties in obtaining legal documentation after lacking the student Visa that she had when first arrived in the country, and she remained in the country illegally for a period of almost three years. She says that during this time, her attitude was crucial, "I left my country not fearing the challenge because if there's one thing I've never been afraid of it is taking risks, and I made it ... Today, what I cherish most is my independence; I wouldn't want to go back to depending on anyone, least of all my parents. I love my independence!"

Adilson came to Portugal to study Computer Engineering (attending last year) and struggled greatly to keep up with the requirements in the new country, "I was lost ... everything was different, the lifestyle, the weather, life was more stressful, people rushing everywhere (...) once I stood paralysed at the tube's exit, I thought I was going to pass out". After this episode and because of constant emotional unease, Adilson resorted to the psychological support service of the University he attended. He has the following to say about counselling: "In the beginning, it was weird and I was ashamed. I wouldn't tell anyone anything, but it was a good thing for me ... I started to feel more confident every day, I went out more and I spoke more easily to people, and friends came afterwards. I later on realized a lot of Cape Verdean students also went through a bad time in the beginning". The proximity to colleagues and friends brought "Cape Verde's heat". “(..) I missed it... there was a residence only made up of Cape Verdean people and we used to play and sing 'mornas' and I laughed all the time. We were happy (...) I want to finish my studies and stay here, me and a lot of my friends. This way we get to be together with the assurance that we're home".

For Angela, the entry into the job market as a hairdresser has allowed her to regain financial security and a regular legal situation. But above all, according to her, there is a possibility to find a piece of Cape Verde here. She further admits, "(...) in the hair salon alone, I met four of my family members. We started talking, not knowing we were related ... I also found a neighbour whom I had not seen in so long ... In the train station, I find people I haven't seen in years!" Ângela summarises the dynamic relationship with the two worlds she inhabits: "It's because, deep down, I can't live away from it. I'm here as if I'm there and I'm there as if I'm here (...)"

Ângela worked at a Private Welfare Institution, did volunteer work in a Cape Verde Association and also continued with church activities. There was not enough time for everything she wanted to do. "I was there last year on vacation, and it was weird ... I had to always be occupied, because if I stopped, I had the urge to go back again ... I missed Portugal. It was only a couple of days, but I did. (...) I ended up liking the stress here! But, when I'm here, I think a lot about my brothers and nephews; I miss them, the sea, the beach".

\section{The world is overseas}

Diogo, 26 years, was born in São Vicente and he has been in Portugal for eight years. He was born in a family but was "taken" (a term used in Cape Verde) by another family he has since accepted as his own: "What I feel for the person I call mum isn't the same, because since before I knew I was somebody, it was her with me until now, and that's why I call her my mum. She took me in when I wasn't even a year old ..."

Miguel, 30, came from Fogo Island to Portugal around nine years ago. "I grew up amongst women", he says, referring to his family of origin consisting of his mother, grandmother and three sisters, who worked long hours to make a living for the family under dire financial circumstance. He has a positive recollection of his upbringing because he felt taken care of in this feminine universe. However, concerning other periods of life, such as his teenage years, he is not as positive, "I was a bit fed up with them ... I mean ... I adore them and all but I was tired of them, always fussing, always wanting to know everything ..." 
He left Cape Verde when he got accepted into a University in Portugal with a Cape Verde scholarship offered by the government, and he desired to leave the country for the challenge of exploring a new country, "It was my first time leaving Cape Verde; I've always wanted to travel abroad. I was in ecstasy, yes, in ecstasy. Everything was new ... I always went around with a smile on my face, back in those days".

Diogo arrived in Portugal to study computer engineering and faced great difficulties keeping up with the formal standards of education, orienting and sorting himself in the geographical space and dealing with bureaucratic and administrative issues. "In the beginning, everything was hard. I used to say that I couldn't do it ... I got discouraged. I said: 'I'm going back home! This isn't for me!'” The presence of family and Cape Verdean friends made the familiarisation of space and school learning possible. "I have a friend here (...) we are from the same Cape Verde region, and she had already been here from August. When I arrived, she took me to the school and introduced me to a boy from Fogo Island. He taught me calculus, and I stopped going to classes and started getting lessons from him..."

The arrival in Portugal for Miguel was a mix of interest in exploring what was new and appealing in a new country, in a very 'positive and optimistic' way. At that time, he lagged behind in school performance due to the standards of the Sociology course as well as difficulties relating to Portuguese colleagues, "(...) because I always had an answer at the tip of my tongue. I wanted to have fun and make friends quickly, and I thought being from Cape Verde or Portugal was all the same. It took a while for me to grasp the fact that it wasn't. But oh well, it turned out alright".

After an initial adjustment period, Diogo took a liking to living in Portugal. Contrasts with Cape Verde were highlighted through the size of urban centres in Portugal, in terms of economic and employment opportunities and through the impact of globalisation, for which food chains are a good example: "McDonald's is one thing I find fascinating about people. When I arrived here, I was like them ... I wouldn't cook, and I ate out many times. I liked the food, and I started liking it even more. There was no McDonald's in Cape Verde! I don't know if there is one in Africa ... in South Africa, maybe". This urban dimension of Portugal first entered Diogo's house in Cape Verde through his older sister who studied in Portugal. "When my sister came to Cape Verde on holiday, she spoke of the Colombo shopping centre. And us Cape Verdeans, in terms of sports, we also root for Benfica, Sporting or Porto [Portuguese football teams]. I saw the stadium of Benfica in my mind and I dreamt of playing football too. I guess I was not very surprised at what I saw when I arrived".

In adjusting with modernity in Lisbon, Diogo was having difficulties in interpersonal relationships with Portuguese people in public spaces, where different forms of discrimination prevailed: "I have also been to a club where the security guy was from Cape Verde, and he told me that me and my friend who used to go there could go in, but my other friends couldn't because his boss didn't let a lot of people in ... a lot of black people".

Over time in Portugal, Miguel started to appreciate different perspectives, namely those showing flexibility and valuing differences between cultures. He recognised the importance of leaving Cape Verde so he could understand these dynamics. "Now I know a couple of bars, in the fashion of a residence, where everybody interacts. I get to talk to people of various cultures, I can foresee things, I understand more, I open my mind more ..." The contrasts between countries was more apparent in the dimension of gender roles, recognizing Cape Verde as a much more conservative society: "anyone that leaves Cape Verde to go somewhere else has a different view than those who stay because there are boys or men who are chauvinists and don't let women do stuff, and when I get here, I acquire a new perspective".

\section{To stay or to go back? Missing morabezza}

Mayra, 23, born on the island of Sal, had a childhood marked by a serious illness in the immune system that required constant hospitalisations. For this reason, parents and family redoubled care and have become "very protective" of her. Family members made joint efforts to help care for Mayra with particular emphasis from her father.

It was Mayra's father who helped her prepare for her stay in Portugal (in a marketing course), alerting her to the difficulties that she would face. He too had studied in Portugal, as well as several other family members. "He started giving me advice and told me I would experience a lot of difficulties here, that I had to always be really strong to face them ... the majority of my family members studied abroad..."

Lúcio, 24, was born in São Nicolau in a small family with sound financial resources and independent businesses. The family lived around the benefits and advantages that the economic situation provided. The family business was quite significant, functioning in an advantageous socio-economic environment.

Joseph, 27, a native of Santiago, asserts that he is from the "entire Cape Verde". Because of his father's profession, he ended up living in four different islands. For this reason, he was very close to his 
siblings, because his friends got lost in the frequent relocations that marked his childhood up to high school: "that's why I say that travelling to Portugal was crossing only a bit more of sea than I'm used to".

Mayra (student) arrived in Portugal (4 years ago) to study environmental engineering and shares the difference she felt between the time she first arrived and the present. Upon her arrival in Lisbon, two dimensions were assured. The first one was family members who helped her understand the paperwork related to student visa, tax card, bank account, and she states, "I didn't need to do it, because they took care of everything for me". The second one was the colleagues and friends from Cape Verde who facilitated her school adaptation. "In the same classroom, same class, I met two Cape Verdeans, and, together with them, I was able to adapt. But as far as the rest goes, it was pretty hard. When one finds, for instance, a Cape Verdean, one can deal and adapt a lot better than with Portuguese people ..."

Like Mayra, Joseph recognised the importance of family at the time he came to Portugal to study Computer Science. "I lived with my sister for two weeks. She was moving from her house when I stayed at the place she was at with two people I already knew. They taught me the tube's map, the Embassy location, the University and where other such places were at". Just like the others, Joseph faced increased difficulties in establishing contact with Portuguese students and the Portuguese population in general. "When I studied, I thought it was only something related to school groups, but later I realized that it was normal, that Portuguese people don't like Cape Verdean people much. At work, people say African people are lazy". After six years in Portugal, Joseph is doing an internship in a company, still with an undefined contractual situation. "I miss my friends and family, I talk to them every day, my father asks me why I don't return to Cape Verde and I think: what am I doing here?"

Lúcio, living in Portugal for three years (still a student of Aerospace Engineering), felt the initial period in Portugal was quite hard due to two main reasons: the difficulty in achieving standard performance in school subjects and the reduced interaction with Portuguese people who constituted the majority of individuals in the private university he attended, with perceived devaluing relationships. "I'm not saying that everybody is like that but some people in my school are actual racists. They already have established groups. If someone wants to be part of them, they always have excuses to turn people down".

For Mayra, the network of family and friends from Cape Verde took the edge out of the initial impact. However, she felt quite alone in between the time spent in school and the time at home studying or talking to family members of Cape Verde through Skype. She mentions the difficulty in relating with Portuguese people, and infrequent gatherings with Cape Verde friends seemed to duplicate the environment of Cape Verde tradition: "I go out with my friends once in a while, I go to parties or even to a friend's house, we laugh, seat, talk ... In Cape Verde, this is called "Xintada", where there are drinks, food, chatting, music and the atmosphere is more private; nothing fancy. I spend more time at home and at school than anywhere else".

For Lúcio, the dimension of relationships and interactions, coupled with a decline in household incomes in his family in Cape Verde, had an adverse effect in his life in Portugal. He found it difficult to gather enough money to pay for school and food every month: "In the beginning, I was still alright. When I started going to school, everything got worse ... and I ended up sadder. At the end of the first couple of months after class, I went out and told my brother, 'I'm going back to Cape Verde!' I was crying and I said, 'I can't do this anymore, I'm returning to Cape Verde!"' However, sharing the house with friends, his brother and other Cape Verde colleagues allowed him to stay and re-invest in school goals. "On Fridays for instance, after an entire week of studying, I met at a café with friends or we played football once in a while. We even had a Cape Verde team of students in Lisbon".

Mayra, Lúcio and José all agree on the importance of the family in Cape Verde and the relationship they maintained with them through existing technologies. The relationships with close family were also maintained through regular visits to Portugal as well as through the trips to Cape Verde during work and school holidays. The plan or possibility of returning to their country of origin, in the short or medium term, was also a common agreement among the three.

\section{DISCUSSION}

This study aimed to understand the resilience processes in Cape Verdean migrants in Portugal through the meanings attributed by them to their life paths. We examined the continuity of subjectivity processes between the country of origin and the host country. We used the lens of transnationalism to understand the interaction between adversity and resources towards cultural adjustment, exploring the connection between past and present experiences and the social and cultural contexts of both countries. Therefore, the method of biographical narratives suited this purpose, allowing access to life paths and migration processes through the reconstruction method (Fischer-Rosenthal \& Rosenthal, 2004).

The narratives shared a common ground on the reason of migration: all of them left the country of origin in order to continue their studies in Portuguese universities. For many of these young migrants, 
there is a Cape Verdean continuity that remains in Portugal through people and environments. Some of them wish to return to their country after completion of studies, which makes coming to Portugal a temporary migration (although most of them end up staying even after considering the possibility of returning), as highlighted also by Meintel (1984).

Regarding life in Cape Verde, dimensions of difficulties for the migrants were found in significant relationships with others or major losses of these people during childhood. Difficulties were also related to the social and cultural contexts, such as conservatism and patriarchy. The other significant dimension in the country of origin concerned the socio-economic condition characterised by low incomes. A majority of these migrants received a scholarship from the Cape Verde Government to complete their education in Portugal, as confirmed by Cape Verde Government data on students. The economic difficulties for the migrants persisted in Portugal, initially because the scholarship was insufficient to cover the costs. Later, due to poor school performance, most of these students lost their scholarship, compelling them to manage studies with precarious jobs.

In general, these migrants were supported by a family organisation in the country of origin, aimed at continuing the children's studies and aspiring for social mobility-a prospect of a better lives than their parents (Suárez-Orozco, Suárez-Orozco, \& Todorova, 2008; Seabra, 2010).

Another very important resource was Cape Verde's Diaspora in Portugal (Carling \& Barta, 2008). Information about the country and on Portuguese people reached Cape Verde long before migrants left the country, beginning a first contact with Portuguese culture and some operating social systems of the country (Meintel, 1984). This Diaspora, directly related to the idea of transnationalism (Anthias 1998; Butler, 2001; Cohen 1997), was an important resource on arrival in the host country, as discussed below.

Despite this previous contact, Cape Verde migrants signalled periods of greater adversity in Portugal. One of the adverse conditions, as mentioned above, was due to the financial situation of many migrants due to low scholarship amount or, in some cases, the loss of this amount. Those who were already entrenched in the job market apparently managed to regain a stable, if not favourable, financial condition at least better than the one they had in Cape Verde or during their time as students.

There was an initial difficulty specifically regarding the academic scenario due to the large disparity between the two countries in the standard of teaching methods and level of content transmitted, as outlined in studies by Évora (2013) on Cape Verdeans in higher education. Previous studies revealed difficulties in the schooling of migrants in Portugal (Machado, Matias, \& Leal, 2005; Marques \& Martins, 2005; Cardoso, 2006). In this academic context and outside too, the adversities were related to two main dimensions: cultural differences and interpersonal relationships with the Portuguese people. The first dimension includes aspects of cultural practices, such as climate disparities, linguistic differences, accelerated life rhythm and difficulties in spatial orientation in the city. The second dimension involves the devaluing nature of relationships with Portuguese people (through rejection and prejudice). The Portuguese society and cultural context is globally perceived as hostile, as in the Challinor (2008) studies on Cape Verde identity, in which these dimensions of life for Cape Verde people in Portugal are highlighted.

The analysis of the narratives also showed two central dimensions at the level of resources: sense of belonging and attachments established through emotional ties. These dimensions were the main resources that allowed overcoming adversity in the resilience process. The feeling of belonging is part of the need for security and to be emotionally attached to people and places, pursuing the feeling of being at home (Lovell, 1998). This sense of belonging is directly related to the possibility of establishing emotional ties through close relationships with others (Sroufe \& Waters, 1977). In the words of Guibernau (2013, pp. 27), 'belonging by choice assumes that the individual is, to a certain extent, free to choose among a set of different options. The act of choosing entails a personal decision and a personal commitment to be acknowledged by other members of the group. It fosters a sense of belonging emerging out of the individual's active engagement in the construction of his or her own self-identity to be defined by means of his or her identification with the group'. In this study, migrants demonstrated the importance of this resource by the way Cape Verde's Diaspora in Portugal allowed the sense of cultural belonging and emotional ties.

The Diaspora in the form of emotional ties with friends from Cape Verde allowed softening the impact on arrival in Portugal. The initial period tended to be disorganised, with difficulty in understanding habits, customs and other cultural practices of the new country in the spatial orientation or in the mental space. These friends and family members from Cape Verde were an important resource to face the impact of pragmatic difficulties, namely the bureaucratic context of permanent visas, the difficulty in finding a house or financial hardships. Simultaneously, while softening the initial impact, these ties allowed for Cape Verde cultural practices to be carried out or for the use of Creole as language, thus ensuring the sense of belonging. 
Over time, the connection with the Diaspora regained new and different configurations. According to some authors (Faist, 2010), the attachments and belongings related with the Diaspora are not always built towards the country and culture of origin. On the contrary, there are many possibilities and configurations (Vertovec, 1999; 2001; Appadurai 1996). These different configurations are the products of resilience processes in terms of cultural adjustment, occurring in different ways. In this study, we observed migrants of the first group that reported a significant tension of attachments between the country of origin and the host country, simultaneously with the transformation of cultural practices of origin and diffuse feelings of belonging. In the second group, the relationship with the country of origin was guided by the established relationship with other Cape Verde people living in Portugal that recreated the Cape Verde environment and culture but with the traits of Portuguese people and Portugal. In the third group, the sense of belonging was developed through globalisation coupled with the cosmopolitanism of European societies, with a tendency to diversify the significant attachments in terms of cultural origin. The fourth group preserved the belonging and attachment to people, places and culture of origin while maintaining the connection with their own country through technologies that allow for permanent contact and the movement of people between Cape Verde and Portugal. These various configurations found in the four groups highlight the fluid nature of the relationship of migrants in the Diaspora, through mixed relations with the host country's culture or other cultures - interactions of products from a context of globalisation in major cities. The hybrid dimension of this diaspora, as noted by several authors (Faist, 2010; Safran, 1991), stands out for the importance of considering the resilience process as fluid also towards cultural adjustment, occurring in different ways for the migrants participating in this study.

\section{CONCLUSION}

This analysis of the narratives reinforces the understanding of resilience processes not as a result but as a complex and intertwined process between conditions and contexts, similar to authors that point out the interest in the concept of resilience in this dynamic and complex dimension (e.g. Luthar et al., 2000). It is also a concept that highlights the contributions of culture specificities (Ungar, 2008) but focuses on individual subjectivity and specificity (Yunes, 2003). The resilience process of migrants in this study assumes several configurations, such as the annulment of adversity's impact, developing alternative possibilities or overcoming adversities by integrating them into trajectories and life paths. It is important to note that these are naturally unfinished processes. The subjective meanings and aspects of individual migrants change over time and due to changes and shifts in the individual life paths. This aspect of mutability is stressed by the authors of the narratives analysis method (Fischer-Rosenthal \& Rosenthal, 2004), which emphasise the hypothetical and temporary nature of the results.

In terms of the implications of clinical work with migrants, this study can be of great importance considering the way issues related to the country of origin are evaluated, since many migrants had life paths marked by adverse conditions even before migrating. As such, these hard conditions in the origin country may be related to difficulties experienced in the host country, where they are significant and recreated, therefore, requiring the attention of clinicians. On the other hand, in this article, we identify the dimensions of belonging and social, cultural and emotional attachments related to the need to be accepted. As such, the therapeutic relationship may constitute the possibility to develop important emotional ties in a therapeutic space (Bordin, 1994).

Regarding the limitations of this study, we concede to the fact that the analysis of narratives is always hypothetical and temporary in nature, as suggested by the authors (Fischer-Rosenthal \& Rosenthal, 2004). This implies that the analysis in this study will certainly change with the permanence of migrants over time in the host country. Another limitation is regarding the fact that the study was conducted with Cape Verdean migrants who shared the commonality of leaving the country of origin to pursue further studies in Portuguese universities. This analysis is possibly insufficient to analyse the experiences of the Cape Verdean migrants who arrive in Portugal in other contexts and age groups. Due to this specificity of young participants and their stay in Portugal (only three years in some cases), the biographical narratives contained little information on life in Cape Verde, making it difficult to capture the sense and meanings they attribute to this period before migration.

\section{References}

American Psychological Association (2002). Ethical principles of psychologists and code of conduct. American Psychologist, 57, 1060-1073. http://dx.doi.org/10.1037/0003-066X.57.12.1060

Âkesson, L., Carling, J., \& Drotbohm, H. (2012). Mobility, moralities and motherhood: Navigating the contingencies of Cape Verdean lives. Journal of Ethnic and Migration Studies, 38, 237-60. http://dx.doi.org/10.1080/1369183X.2012.646420 
Anthias, F. (1998) Evaluating diaspora: Beyond ethnicity. Sociology, 32, 557-81. http://dx.doi.org/10.1177/0038038598032003009

Apitzsch, U., \& Siouti, I. (2007). Biographical analysis as an interdisciplinary research perspective in the field of migration studies. Frankfurt am Main: Research Integration, Johann Wolfgang Goethe Universität, University of York.

Appadurai, A. (1996) Modernity at large. Cultural dimensions of globalization. Minneapolis: University of Minnesota Press.

Batalha, L. (2008). Cabo-verdianos em Portugal: Comunidade e identidade. In P. Góis (Orgs). Comunidade(s) Cabo-verdiana(s): As múltiplas faces da imigração Cabo-verdiana [Cape Verde(an) comunity(ies): The multiple faces of Cape Verdean immigration] (pp. 25-36). Colecção Comunidades, 2, Lisboa: Alto Comissariado para a Imigração e Diálogo Intercultural.

Basch, L., Schiller, N., \& Szanton-Blanc, C. (1994). Nations unbound: Transnational projects, postcolonial predicaments and deterritorialized nation-states. Amsterdam: Gordon and Breach.

Butler, K. (2001) Defining diaspora, refining a discourse. Diaspora: A Journal of Transnational Studies, 10 , 189-219. http://dx.doi.org/10.1353/dsp.2011.0014

Cardoso, S. (2008). O dualismo cultural: os luso-cabo-verdianos entre a escola, a família e a comunidade [Cultural dualism: the Portuguese-Cape Verdean between school, family and community]. (Doctoral dissertation). Universidade do Minho. Retrieved from https://repositorium.sdum.uminho.pt/bitstream/1822/7717/3/Tesereprodução.pdf

Carling, J. (2002). Migration in the age of involuntary immobility: Theoretical reflections and cape verdean experiences. Journal of Ethnic and Migration Studies 28, 5-42. http://dx.doi.org/10.1080/13691830120103912

Carling, J., \& Batalha, L. (2008). Cape Verdean migration and diaspora. In J. Carling \& L. Batalha (Eds), Transnational archipelago. Perspectives on Cape Verdean migration and diaspora (pp. 13-31). Amsterdam: Amsterdam University Press.

Carita, C., \& Rosendo, V. N. (1993). Associativismo cabo-verdiano em Portugal: Estudo de caso da Associação Cabo-verdiana em Lisboa. [Cape Verdean associations in Portugal: A case study of Cape Verdean Association in Lisbon]. Sociologia-Problemas e Práticas, 43, 135-152.

Carling, J. (2004). Emigration, return and development in Cape Verde: The impact of closing borders. Population, Space and Place, 10, 113-132. http://dx.doi.org/10.1002/psp.322

Challinor, E. P. (2008). Home and overseas: The Janus faces of Cape Verdean identity. Diaspora: A Journal of Transnational Studies, 17, 84-104.

Cohen, R. (1997). Global Diasporas: An Introduction. Seattle: University of Washington Press.

Évora, G. (2013). Sucesso escolar nos alunos de origem cabo-verdiana: O caso dos alunos que ingressam no ensino superior [Educational achievement in students of Cape Verdean origin: The case of students entering higher education]. (Doctoral dissertation). Universidade Nova. Retrieved from http://run.unl.pt/handle/10362/10954

Évora, I. (2006). De emigrantes/imigrantes a migrantes transnacionais; possibilidades e limites de uma nova categoria de análise da identidade e migração Cabo-verdianas [From emigrant / immigrant to transnational migrants; possibilities and limits of a new category of identity analysis and Cape Verdean migration]. Comunicação apresentada ao 3o Congresso da APA - Afinidade e Diferença. Lisboa.

Faist, T. (2010). Diaspora and transnationalism: What kind of dance partners. In R. Bauböck, \& T. Faist (Eds.), Diaspora and transnationalism: Concepts, theories and methods (pp. 9-34). Amsterdam: Amsterdam University Press.

Fisher-Rosenthal, W., \& Rosenthal, G. (2004). The analysis of narrative-biographical interviews. In U. Flick, E. von Kardorff, \& I. Steinke (Eds.), A companion to qualitative research (pp. 259-265). London: Sage Publications.

Grassi, M. (2006). Cabo Verde pelo mundo: 0 género na diáspora cabo-verdiana [Cape Verde in the world: Gender in the Cape Verdean diáspora]. In M. Grassi \& I. Évora (Orgs.), Género e migrações CaboVerdianas (pp. 23-61). Lisboa: Imprensa de Ciências Sociais.

Góis, P. (2008). Entre Janus e Hydra de Lerna: As múltiplas faces dos cabo-verdianos em Portugal [Between Janus and Hydra: The many faces of Cape Verdeans in Portugal]. In P. Góis (Orgs), Comunidade(s) Cabo-verdiana(s): As múltiplas faces da imigração Cabo-verdiana. Colecção Comunidades, 2 (pp. 9-24). Lisboa: Alto Comissariado para a Imigração e Diálogo Intercultural.

Góis, P., \& Marques, J. C. (2008). Práticas transnacionais dos imigrantes cabo-verdianos em Portugal [Transnational practices of Cape Verdean immigrants in Portugal]. In P. Góis (Orgs), Comunidade(s) Cabo-verdiana(s): As múltiplas faces da imigração Cabo-verdiana. Colecção Comunidades, 2 (pp. 86104). Lisboa: Alto Comissariado para a Imigração e Diálogo Intercultural. 
Hollway, W., \& Jefferson, T. (2000). Doing qualitative research differently: Free association, narrative and the interview method. London: Sage.

Lovell, N. (1998). Locality and belonging. London: Routledge.

Luthar, S. S., Cicchetti, D., \& Becker, B. (2000). The construct of resilience: A critical evaluation and guidelines for future work. Child Development, 71, 543-562. http://dx.doi.org/10.1111/14678624.00164

Machado, I. J. (2006). Imigração em Portugal [Immigration in Portugal]. Estudos Avançados, 20, 119-135. http://dx.doi.org/10.1590/S0103-40142006000200010

Machado, F., Matias, A., \& Leal, S. (2005). Desigualdades sociais e diferenças culturais: Os resultados escolares dos filhos de imigrantes africanos [Social inequalities and cultural differences: The educational achievement of children of African immigrants]. Análise Social, XL(176), 695-714.

Marques, M., \& Martins, J. (2005). Jovens, migrantes e a sociedade da informação e do conhecimento - A Escola perante a diversidade [Young people, migrants and the information society and knowledge The School faced with diversity]. Lisboa: Alto-Comissariado para as Minorias Étnicas.

Meintel, D. (1984) Emigração em Cabo Verde: Solução ou problema? [Emigration in Cape Verde: Solution or problem?]. Revista Internacional de Estudos Africanos, 2, 93-120.

Noh, S., \& Kaspar, V. (2003). Perceived discrimination and depression: Moderating effects of coping, acculturation, and ethnic support. American Journal of Public Health, 93, 232-238.

Padilla, A. M., Cervantes, R. C., Maldonado, M., \& Garcia, R. E. (1988). Coping responses to psychosocial stressors among Mexican and Central American immigrants. Journal of Community Psychology, 16, 418-427.http://dx.doi.org/10.1002/15206629(198810)16:4<418::AIDJCOP2290160407>3.0.CO;2-R

Portes, A., Guarnizo, L., \& Landholt, P. (1999). The study of transnationalism: Pitfalls and promise of an emergent research field. Ethnic and Racial Studies, 22, 217-37. http://dx.doi.org/10.1080/014198799329468

Reichertz, J. (2004). Abduction, deduction and induction in qualitative research. In U. Flick, E. von Kardoff, \& I. Steinke (Eds.), A companion to qualitative research. (pp. 159-164). London: Sage Publications.

Richardson, G. E. (2002). The metatheory of resilience and resiliency. Journal of Clinical Psychology, 58, 307-321. http://dx.doi.org/10.1002/jclp.10020

Rosenthal, G. (1993). Reconstruction of life stories: Principles of selection in generating stories for narrative biographical interviews. The narrative study of lives, 1, 59-91.

Rosenthal, G., \& Fischer-Rosenthal, W. (2004). The analysis of biographical-narrative interviews. In U. Flick, E. von Kardorff, \& I. Steinke (Eds.), A companion to qualitative research (pp.259-265) London: Sage.

Safran, W. (1991). Diasporas in modern societies: Myths of homeland and return. Diaspora, 1(1), 83-99. http://dx.doi.org/10.1353/dsp.1991.0004

Seabra, T. (2010). Adaptação e adversidade - o desempenho escolar dos alunos de origem indiana e caboverdiana no ensino básico [Adaptation and adversity - the academic performance of students of Indian and Cape Verdean origin in basic education]. Lisboa: Imprensa de Ciências Sociais.

Serviço de Estrangeiros e Fronteiras (2013). Relatório de imigração, fronteiras e asilo [Immigration, frontiers and asylum report]. Retrieved from http://sefstat.sef.pt/Docs/Rifa_2013.pdf

Seligman, M. (2002). Positive psychology, positive prevention, and positive therapy. In C. R. Snyder, \& S. J. Lopez (Eds.), Handbook of positive psychology (pp. 3-9). New York: Oxford University Press.

Schiller, N. G., Basch, L., \& Blanc-Szanton, C. (1992). Transnationalism: A new analytic framework for understanding migration. Annals of the New York Academy of Sciences, 645, 1-24. http://dx.doi.org/10.1111/j.1749-6632.1992.tb33484.x

Sroufe, L. A., \& Waters, E. (1977). Attachment as an organizational construct. Child Development, 48, 11841199. http://dx.doi.org/10.2307/1128475

Suárez-Orozco, C., Suárez-Orozco, M., \& Todorova, T. (2008). Learning a new land - Immigrant students in American society. London: The Belknap Press of Harvard University Press.

Yakushko, 0. (2010). Stress and coping strategies in the lives of recent immigrants: A grounded theory model. International Journal for the Advancement of Counselling, 32, 256-273. http://dx.doi.org/10.1007/s10447-010-9105-1

Yijälä, A., \& Jasinskaja-Lahti, I. (2010). Pre-migration acculturation attitudes among potential ethnic migrants from Russia to Finland. International Journal of Intercultural Relations, 34, 326-339. http://dx.doi.org/10.1016/j.ijintrel.2009.09.002

Ungar, M. (2008). Resilience across Cultures. British Journal of Social Work, 38, 218-235. http://dx.doi.org/10.1093/bjsw/bcl343 
Vertovec, S. (1999). Conceiving and researching transnationalism. Ethnic and Racial Studies, 22, 447-62. http://dx.doi.org/10.1080/014198799329558

Vertovec, S. (2001). Transnationalism and identity. Journal of Ethnic and Migration Studies, 27, 573-82. http://dx.doi.org/10.1080/13691830120090386

Yunes, M. (2003). Psicologia positiva e resiliência: o foco no indivíduo e na família [Positive psychology and resilience: focus on the individual and the family]. Psicologia em estudo, 8(spe), 75-84. http://dx.doi.org/10.1590/S1413-73722003000300010

Historial do artigo

Recebido 16/02/2016

Aceite $\quad 30 / 10 / 2016$

Publicado $12 / 2016$ 